\title{
Short Communication: Diversity of mosquitoes in Central Java, Indonesia that act as new vector in various tropical diseases
}

\author{
KHARIRI \\ Center for Research and Development of Biomedical and Basic Health Technology, Indonesian National Institute for Health Research and Development. \\ Jl. Percetakan Negara No.23 Jakarta Pusat 10560, Jakarta, email: arie.tegale @gmail.com
}

Manuscript received: 15 September 2018. Revision accepted: 16 October 2018.

\begin{abstract}
Khariri. 2018. Short Communication: Diversity of new mosquitoes in Central Java Province that can act as vector in various tropical diseases. Bonorowo Wetlands 8: 71-74. Mosquitoes transmit many diseases as vectors. The presence of mosquitoes is widespread worldwide, including in Indonesia, with an estimated 3100 species from 34 genera. Vector control is the main thing to do and treatment in patients. Morphological identification of mosquitoes aims to identify the character and number of species to become a picture of diversity in an area. Data collection was carried out from the 2015 Special Research Report on Vector and Reservoir Diseases (Rikhus Vektora) in Central Java Province. The data obtained were analyzed descriptively. Mosquito samples in Rikhus Vektora in 2015 in Central Java Province were collected from 3 different ecosystems, namely forest $(\mathrm{H})$, non-forest $(\mathrm{NH})$, and beach $(\mathrm{P})$. The location of the ecosystem includes near settlements (DP) and far from settlements (JP). Mosquito samples were successfully identified as many as 29,071 tails consisting of 5 genera and 37 species. From Pekalongan, a sample of mosquitoes composed of 5 genera and 19 species was obtained. As many as 4 species of mosquitoes are species that have never been identified and reported circulation in Pekalongan. Identification of mosquitoes collected in Purworejo has 5 genera and 23 species. Mosquito samples from Pati were identified as having 5 genera and 22 species.
\end{abstract}

Keywords: Central Java, mosquitoes, tropical diseases, vectors

\section{INTRODUCTION}

Insects can play a positive role in human life, but some insects harm human health (Sabir et al., 2017). Mosquitoes are small types of insects that harm human health because they act as disease vectors. Some diseases caused by mosquitoes are still a serious health problem in society with the many losses incurred (Islamiyah et al., 2013). The presence of mosquitoes is widespread worldwide, including in Indonesia, with an estimated 3100 species from 34 genera. Some mosquitoes that became disease vectors include Aedes aegypti and Aedes albopictus causing Dengue Hemorrhagic Fever (DHF) and chikungunya, 19 mosquitoes from the Anopheles genus causing malaria, 27 mosquitoes from the genus Culex, Anopheles, Aedes, and Mansonia causing filariasis (Marbawati and Sholichah, 2009).

At present, there have been many reports of diseases transmitted by mosquitoes as vectors. The many losses caused by the disease so that an effort to eradicate the disease needs to be done (Sabir et al., 2017). Eradication of disease through vector control programs is the main thing to do and treatment in patients (Kazwani and Mading, 2014). Mosquito control programs as disease vectors will be maximized if there is a match between mosquitoes' behavior targeted by the control methods used (Mahdalena et al., 2016). Mosquitoes have a high diversity of species with habitats for female breeds, which are very diverse, ranging from semi-aquatic places to wide water systems
(Suwito, 2007). The proper morphological identification of mosquitoes can identify the character and number of species to become a picture of diversity in an area (Fahmi et al., 2014).

Indonesia is an archipelago with a tropical climate that is heterogeneous and vulnerable to regional and global climate change. Macro and microclimate changes can affect the spread of infectious diseases, including contagious diseases of mosquito vectors. Increased humidity and rainfall are directly proportional to the increase in mosquito density, while the temperature has an optimum limit for mosquito breeding between $25-27^{\circ} \mathrm{C}$. Central Java Province is still an endemic area for several diseases transmitted by mosquitoes as a vector (Suwito et al., 2010).

\section{MATERIALS AND METHODS}

Analysis was carried out on data from the 2015 Special Research Report on Vector and Reservoir Diseases (Rikhus Vektora) in Central Java Province, Indonesia (MoH 2015). The collection of mosquito samples was carried out in 3 districts in Central Java, namely Pekalongan, Purworejo, and Pati. Mosquito samples were collected from 3 different ecosystems, namely forest $(\mathrm{H})$, non-forest $(\mathrm{NH})$, and beach (P). The location of the ecosystem includes near settlements (DP) and far from settlements (JP). Mosquito samples were identified and tested in the laboratory to 
confirm the species and disease agents they brought. Laboratory checking using Polymerase Chain Reaction (PCR) includes dengue, malaria, chikungunya, JE, and filariasis for mosquito samples. The data obtained were analyzed descriptively.

\section{RESULTS AND DISCUSSION}

Mosquito samples were identified and tested in the laboratory to confirm the species and disease agents they brought. Laboratory tests were carried out using the Polymerase Chain Reaction (PCR) method to detect DHF, malaria, chikungunya, Japanese encephalitias (JE), and filariasis. The total samples of successfully identified mosquitoes were 29,071 tails consisting of 5 genera and 37 species. From Pekalongan District, there were mosquito samples consisting of five 5 and 19 species, Purworejo District consisting of 5 and 23 species, and Pati District consisting of 5 and 22 species. Complete results can be seen in Table 1.

Four mosquitoes among the 24 species found in Pekalongan District have never been identified and reported in Pekalongan District, namely Aedes subgenus finlaya, Ar. durhami, Ar. kucingensis, and Ar. pectinatus. The laboratory tests on samples collected from Pekalongan District obtained positive Aedes aegypti containing DHF virus as much as $26.7 \%$, while malaria Japanese encephalitias (JE) filariasis examinations were negative. In samples collected from Purworejo District and Pati District, laboratory tests for detecting dengue virus, Japanese encephalitias (JE), malaria, and filariasis showed negative results.

Almost all regions in Central Java except Wonosobo become deadly disease-endemic areas, namely DHF. The highest cases of elephantiasis or filariasis in Central Java occur in Pekalongan City. The Central Java Provincial Health Office reported 442 cases of filariasis in the May 2017 period occurring in Pekalongan City. This figure far exceeds the cases occurring elsewhere in Central Java which only reach two digits.

DHF has become a health problem prioritized in Central Java Province because DHF cases are still the third-highest in Indonesia in 2015 (Fatati 2017). Pekalongan District is one of Central Java Province regions with a serious dengue disease problem. Pekalongan District Health Office has reported that the Incidence Rate (IR) of DHF in Pekalongan District tends to increase every year. In 2012 it increased to 15.17 / 100,000 population and increased again in 2013 to 33.6 / 100,000 population (Widiastuti and Ikawati, 2016).

Pekalongan District is also one of the regencies in Central Java Province, which is included in filariasisendemic areas. Pekalongan District Health Office has reported that chronic filariasis continues to increase in
2011. All mosquito species can play a role in infectious filariasis. More than 23 species of mosquitoes are estimated to occur in Indonesia and become filariasis transmission vectors consisting of the genera Anopheles, Aedes, Culex, Mansonia, and Armigeres. Someone will show symptoms of filariasis with several bites of mosquitoes that have been infected with filaria for a long time.

Purworejo District is in Central Java Province, with the highest number of DHF patients in Java. Data from Purworejo District Health Office stated that dengue cases often appear in Purworejo District and are increasingly widespread with relatively high IR and CFR. The number of dengue cases continues to increase until 2016 to 447 patients with morbidity rates of 58 / 100,000 population. This number still exceeds the national figure of $20 /$ 100,000 population (Yana, 2017). The highest malaria case in Central Java also occurred in Purworejo District. A total of 6 sub-districts from 16 sub-districts in Purworejo District were included in malaria-endemic areas. This amount is the highest number of districts that have malaria endemic in Central Java Province. The six sub-districts are Bener, Bagelen, Gebang, Loano, Kaligesing, and Kemiri Sub-districts (Lestari et al., 2007).

DHF is still a serious problem in Pati District, as evidenced by 29 existing health centers that have been infected with DHF. DHF morbidity rate in Pati District in 2015 amounted to 74.9 / 100,000 population increased compared to 2014 amounting to 23.2 / 100,000 population. The highest morbidity rate in Kayen with 43 cases and the lowest in Tayu I Health Center was not found in DHF cases. Every DHF patient who reported treatment was carried out, epidemiological investigations in the field, and control efforts.

A report from the Pati District Health Office in 2015 stated that morbidity is an indicator to monitor the progress of malaria. The number of clinical malaria sufferers in Pati District in 2015 was 82 people with positive malaria, as many as 56 down compared to 2014 as many as 312 people with positive malaria 118 people. The morbidity of malaria in Pati District is more due to migration from endemic areas to Pati District. In 2015 filariasis cases were found as many as 1 people, and up to 2015, in Pati District, there were 14 cases ( 1 / 100,000 population).

Changes in global temperature will affect climate change and increase environmental health risks for humans. Exposure to environmental changes can cause various health problems, one of which is related to disease vectors (Yanuarini 2015). Malaria is an infectious disease that is sensitive to climate change. It is estimated that the average global temperature will increase by $1.0^{\circ}-3.5^{\circ} \mathrm{C}$ by 2100 , increasing the number of vector-borne diseases and the transmission of disease. Climate change will have a longterm and short-term impact on malaria transmission. In the short term, it can be seen in temperature and rainfall (Githeko 2000). 
Table 1. Distribution of species and number of mosquitoes caught based on ecosystems

\begin{tabular}{|c|c|c|c|c|c|c|c|}
\hline \multirow{2}{*}{ Species } & \multicolumn{6}{|c|}{ Ecosystems } & \multirow{2}{*}{ Total } \\
\hline & HDP & HJP & NHDP & NHJP & PDP & PJP & \\
\hline Aedes aegypti & 0 & 0 & 58 & 2 & 13 & 1 & 74 \\
\hline Aedes albopictus & 97 & 131 & 97 & 91 & 22 & 12 & 450 \\
\hline Aedes poecilus & 0 & 44 & 0 & 0 & 0 & 0 & 44 \\
\hline Aedes scutellaris & 0 & 7 & 0 & 0 & 0 & 0 & 7 \\
\hline Aedes sp. & 100 & 2 & 2 & 0 & 0 & 10 & 114 \\
\hline Aedes subgenus finlaya & 0 & 2 & 0 & 0 & 0 & 0 & 2 \\
\hline Aedes vexans & 0 & 0 & 0 & 10 & 0 & 45 & 55 \\
\hline Anopheles aconitus & 19 & 2 & 1 & 1 & 0 & 0 & 23 \\
\hline Anopheles annularis & 20 & 9 & 1 & 0 & 0 & 0 & 30 \\
\hline Anopheles balabacensis & 1 & 34 & 0 & 0 & 0 & 0 & 35 \\
\hline Anopheles barbirostris & 154 & 62 & 47 & 267 & 12 & 17 & 559 \\
\hline Anopheles leucosphyrus & 3 & 0 & 0 & 0 & 0 & 0 & 3 \\
\hline Anopheles indifinitus & 2 & 0 & 2 & 1 & 218 & 9 & 232 \\
\hline Anopheles kochi & 25 & 1 & 0 & 4 & 0 & 0 & 30 \\
\hline Anopheles maculatus & 567 & 191 & 0 & 0 & 0 & 0 & 758 \\
\hline Anopheles peditaeniatus & 207 & 0 & 0 & 0 & 0 & 0 & 207 \\
\hline Anopheles tesselatus & 0 & 0 & 0 & 1 & 0 & 0 & 1 \\
\hline Anopheles subpictus & 2 & 0 & 12 & 7 & 847 & 1124 & 1992 \\
\hline Anopheles vagus & 54 & 0 & 4 & 35 & 188 & 14 & 295 \\
\hline Armigeres durhami & 3 & 1 & 0 & 0 & 0 & 0 & 4 \\
\hline Armigeres kucingensis & 25 & 33 & 2 & 10 & 3 & 0 & 73 \\
\hline Armigeres pectinatus & 1 & 3 & 0 & 0 & 0 & 0 & 4 \\
\hline Armigeres sp. & 1 & 0 & 0 & 0 & 0 & 0 & 1 \\
\hline Armigeres subalbatus & 51 & 9 & 118 & 731 & 57 & 1 & 967 \\
\hline Culex bitaeniorhyncus & 0 & 5 & 1 & 18 & 1053 & 604 & 1681 \\
\hline Culex fuscocephalus & 0 & 2 & 0 & 0 & 6 & 3 & 11 \\
\hline Culex gelidus & 4 & 0 & 4 & 4 & 160 & 15 & 187 \\
\hline Culex hutchinsoni & 0 & 0 & 0 & 0 & 2 & 0 & 2 \\
\hline Culex pseudovishnui & 920 & 113 & 54 & 936 & 206 & 536 & 2765 \\
\hline Culex quinquefasciatus & 126 & 10 & 810 & 562 & 1299 & 572 & 3379 \\
\hline Culex sp. & 2 & 1 & 0 & 0 & 0 & 0 & 3 \\
\hline Culex tritaeniorhyncus & 1854 & 373 & 524 & 2507 & 1165 & 530 & 6953 \\
\hline Culex vishnui & 1086 & 363 & 251 & 1944 & 275 & 1230 & 5149 \\
\hline Culex sitiens & 0 & 0 & 0 & 0 & 304 & 2370 & 2674 \\
\hline Mansonia uniformis & 0 & 7 & 0 & 5 & 9 & 0 & 21 \\
\hline Mansonia dives & 1 & 6 & 1 & 0 & 146 & 131 & 285 \\
\hline Malaya sp. & 1 & 0 & 0 & 0 & 0 & 0 & 1 \\
\hline Total & 5326 & 1411 & 1989 & 7136 & 5985 & 7224 & 29071 \\
\hline
\end{tabular}

Hot and humid air is most suitable for Anopheles mosquitoes. Anopheles mosquitoes appear more frequently in the transition season, but mosquito attacks can be found for most years (Duarsa, 2008). Mosquito species that become malaria vectors have habitats influenced by environmental temperature, vegetation, altitude or topography, food availability, and even some subspecies affected by water $\mathrm{pH}$ and salinity. If the life of a human being is in contact with the habitat of Anopheles mosquitoes, there is a risk of transmission. Mosquitoes breed well if the environment is in accordance with the conditions needed by mosquitoes to breed. Environmental conditions that support the development of mosquitoes are not the same for each type/species of mosquito. Anopheles aconitus mosquitoes are suitable in hilly areas with nontechnical terraced rice fields; many water channels overgrew with grass that inhibits water flow (Harijanto 2009). Anopheles balabacensis mosquitoes are ideal for hilly areas widely found in forests and plantations. Geographical and meteorological factors in Indonesia are beneficial for malaria transmission in Indonesia. The effect of this temperature is different for each species. At a temperature of $26.7^{\circ} \mathrm{C}$, the extrinsic incubation period is 10-12 days for P. palcifarum and 8-11 days for P.vivax, 1415 days for P.malariae, and P.ovale (Yawan 2016).

Malaria transmission includes three main factors: patients with or without clinical symptoms, mosquitoes or vectors, and healthy humans. The local community's physical, chemical, biological, and socio-cultural factors greatly influence the spread of malaria. The interaction of weather and climate change, pond excavation, deforestation, and areas with lots of puddles, bushes, and an unhealthy environment will affect the growth of malaria agents (Hasyim 2014).

Changes in temperature, relative humidity, and rainfall resulted in mosquitoes laying more frequently and 
increasing the number of DHF vectors and viruses to develop more malignantly. The cycle of marriage and the growth of mosquitoes from eggs to larvae and adult mosquitoes will be shortened so that the population will quickly rise. The presence of water reservoirs such as bathtubs, flower vases, drums, used cans, etc., will increase the number of mosquitoes laying eggs (Gama 2010).

Around 400 species of Anopheles mosquitoes have been found worldwide, and 67 species have been proven to be malaria vectors. Among 67 mosquito species, there are 22 species found in Indonesia (Munawar 2005). In Indonesia, there are 80 Anopheles mosquitoes, 19 species of which have been confirmed as malaria vectors. More than 23 species of mosquitoes become filariasis transmission vectors consisting of the genera Anopheles, Aedes, Culex, Mansonia, and Armigeres. Environmental factors affect filariasis vector density. The presence of Aedes aegypti in an area indicates the presence of the Aedes aegypti population in the area. The ideal environment for mosquitoes can be used as a potential place for mosquito breeding and resting places to increase the density of mosquitoes.

\section{REFERENCES}

Duarsa ABS. 2008. Impact of global warming on risk malaria happens Publ Health J 2 (2): 181-185. DOI: 10.24893/jkma.2.2.181-185.2008.

Fahmi M, Fahri, Nurwidayati A, Suwastika IN. 2014. Study on diversity of mosquito species Anopheles sp. in Donggala District, Central Sulawesi Province. J Nat Sci 3 (2): 95-108.

Fatati IF, H Wijayanto H, AM Soleh. 2017. Spatial regression analysis and spread patterns in cases of Dengue Hemorrhagic Fever (DHF) in Central Java Province. Media Statistics 10 (2): 95-105. DOI 10.14710/medstat.10.2.95-105.

Gama A, Betty F. 2010. Risk factors analysis of dengue fever events in Mojosongo Village, Boyolali District. Explanation 5 (2): 1-9.

Githeko A, SW Lindsay, UE Confalonieri, JA Patz. 2000. Climate Change and Vector-borne Diseases: A regional analysis. World Health Organization Bulletin, Geneva.

Harijanto PN, A Nugroho, CA Gunawan. 2009. Malaria from Molecular to Clinical. 2nd edition. EGC Medical Book Publisher, Jakarta, Indonesia.

Hasyim H, Camelia A, Dawn NA. 2014. Determinants of malaria in endemic areas. J Nat Publ Health 8 (7): 291-4. DOI: 10.21109/kesmas.v0i0.367.

Islamiyah M, AS Leksono, ZP Gama. 2013. Distribution and composition of mosquitoes in the Mojokerto Region. J Biotrop 1 (2): 80-85.
Kazwaini M, Mading M. 2014. The type and status of Anopheles spp. as a potential vector of malaria in Sumba Island East Nusa Tenggara Province. J Health Ecol 13 (4): 298-307.

Lestari EW, S Sukowati, Soekidjo, RA Wigati. 2007. Malaria vector in the area of Menoreh Hill, Purworejo, Central Java. Media Litbang Kesehatan 17 (1): 30-35.

Mahdalena V, Hapsari N, Ni'mah T. 2016. Diversity of Anopheles blood sucking types and activities spp. in Simpang Empat Village, Lengkiti Subdistrict, Ogan Komering Ulu, South Sumatra. Aspirator 8 (1): 916. DOI: 10.22435/aspirator.v8i1.3957.9-16.

Marbawati D and Z Sholichah. 2009. Reference collection of mosquitoes in Japanrejo Village, Blora District, Blora District. Balaba 5 (1): 6-10.

MoH. 2015. Report on the 2015 Research and Vector Special Reserves (Rikhus Vektora). Center for Disease Vector and Reservoir, Research and Development, Health Research and Development Agency, Ministry of Health, Jakarta, Indonesia. [Indonesian]

Muhammad R, Soviana S, Hadi UK. 2015. Diversity of species and habitat characteristics of Anopheles mosquito spp. in Datar Luas Village, Aceh Jaya District, Aceh Province. Indones Entomol J 12 (3): 139-48. DOI: 10.5994/jei.12.3.139.

Munawar A. 2005. Risk Factors for Malaria in Sigeblog Village Banjar Mangu Public Health Center Banjarnegara District, Central Java. [Thesis]. Universitas Diponegoro, Semarang, Indonesia.

Nugrahaningsih M, N Adiputra N, Iwrediaryanta. 2010. Relationship between environmental and behavioral factors of the community with the existence of dengue hemorrhagic fever transmission in the north Kuta Health Center. Ecotrophic 5 (2): 93-97.

Sabir M, Annawaty, Fahri. 2017. Inventory of mosquito types in Alindau Village, Donggala, Central Sulawesi. Nat Sci: J Sci Technol 6 (3): 263-9. DOI: 10.22487/25411969.2017.v6.i3.9200.

Suwito A. 2007. Diversity of mosquito types (Diptera: Culicidae) collected from bamboo stumps in National Park Mt. Gede Pangrango and National Park Mt. Mist. Zoo Indones 16 (1): 31-47.

Suwito, Hadi UK, Sigit S, Sukowati S. 2010. Relationship of climate, density of Anopheles mosquitoes and malaria disease. J Entomol Indones 7 (1): 42-53. DOI: 10.5994/jei.7.1.42.

Widiastuti D, Ikawati B. 2016. Malathion resistance and esterase enzyme activity of Aedes aegypti population in Pekalongan District. Balaba 12 (2): 61-70. DOI: 10.22435/blb.v12i2.4475.61-70.

Windiastuti IA, Suhartono, Nurjazuli. 2013. Relationship between home, socio-economic, and behavioral conditions of the community with filariasis in South Pekalongan Subdistrict, Pekalongan City. Indones J Environ Health 12 (1): 51-57.

Yana GF, Suhartono, S Winarni. 2017. Differences in environmental conditions based on Incidence Rate (IR) of Dengue Hemorrhagic Fever (DHF) in the work area of Mranti Health Center Purworejo Year District. J Publ Health 5 (5): 2017.

Yanuarini C. 2015. Factors related to filariasis in Tirto I Health Center Pekalongan District. J Nursing 8 (1): 73-86.

Yawan, SF. 2006. Risk Factors Analysis of Malaria in the Working Area of Bosmik Health Center, Biak Timur District, Biak-Numfor District, Papua. [Thesis]. Universitas Diponegoro, Semarang. [Indonesian] 